\title{
HERBAGE PRODUCTION, NUTRITIVE VALUE AND GRAZING PREFERENCE OF DIPLOID AND TETRAPLOID PERENNIAL RYEGRASS CULTIVARS (Lolium perenne L.)
}

\author{
Oscar A. Balocchi ${ }^{1 *}$, and Ignacio F. López ${ }^{1}$
}

\begin{abstract}
The objective of this study was to determine, under the soil and climatic conditions of Southern Chile, the effect of the ploidy of perennial ryegrass (Lolium perenne L.) cultivars on herbage production, nutritive value, grazing preference and utilization of pasture produced. This study was conducted in southern Chile, Valdivia Province, and was evaluated for 3 years. The tetraploid cultivars used were Quartet (4n), Gwendal (4n), Pastoral (4n) and Napoleon $(4 n)$. The diploid cultivars were Anita $(2 n)$, Jumbo $(2 n)$, Aries (2n), and Yatsyn $1(2 n)$. When the average sward height reached $20 \mathrm{~cm}$, all plots were simultaneously grazed by dairy cows for a period of $24 \mathrm{~h}$. Before and after grazing, sward height, dry matter availability and nutritive value were evaluated. Grazing preference was visually assessed every $5 \mathrm{~min}$ for a period of $2.5 \mathrm{~h}$ after the afternoon milking. During the 3 -year period 20 grazing events were evaluated. A randomized complete block design, with eight cultivars and three replicates, was used. Diploid cultivars showed greater herbage mass accumulation than tetraploid cultivars $(\mathrm{P} \leq 0.05)$. No significant differences were obtained in the annual average crude protein content. Nevertheless, tetraploid cultivars showed a greater D value than diploid cultivars, except during the third year when the difference was not statistically significant. Dairy cows grazed more time on tetraploid cultivars. Considering, additionally, the residual herbage mass after grazing and the percentage of pasture utilization, diploid cultivars were less intensively grazed, suggesting a lower consumption by the cows.
\end{abstract}

Key words: Lolium perenne, grazing preference, herbage mass, ploidy.

\section{INTRODUCTION}

Lolium perenne $\mathrm{L}$. is the most commonly used forage species to establish permanent pastures in southern Chile. In the wild this species is in diploid form $(2 n=2 \mathrm{x}=14)$ (Nair, 2004) and the cultivars traditionally used have been diploids (Gilliland et al., 2007). More than 60 years ago Myers (1939) reported the creation of tetraploid plants $(2 n=4 \mathrm{x}=28)$ of $L$. perenne. However, for a long time these were not widely used in agriculture and it is only in recent decades that there has been increased used of tetraploid cultivars. Gilliland et al. (2007) reported that in Northern Ireland in the last 25 years the use of tetraploid cultivars has increased from 5 to $30 \%$, estimated on the basis of the total of $L$. perenne seeds sold. The use of tetraploid cultivars has also been increasing in Chile in the last decade. The main reason for the interest in tetraploid cultivars is the search for a better productive response from dairy animals. The duplication of the

${ }^{1}$ Universidad Austral de Chile, Facultad de Ciencias Agrarias, Casilla 567, Valdivia, Chile. *Corresponding author (obalocch@uach.cl).

Received: 07 February 2008.

Accepted: 03 June2008. number of $L$. perenne chromosomes generates a series of morphological and physiological changes in the plants associated with an increase in cell size, broadening the cell content/cell wall ratio. The increased proportion of cellular content increases the concentration of soluble carbohydrates, proteins and lipids, and improves forage digestibility (Smith et al., 2001; Nair, 2004).

Tetraploid cultivars have larger seeds than diploids (Nair, 2004), because of which they require a higher seeding rate (Sheldrick, 2000). They have a lower number of large-sized tillers with more intensely green foliage and larger leaves. They require more soil fertility to express their growth potential and are less tolerant of water stress (Sugiyama, 2006). As a consequence of these characteristics, tetraploid cultivars have less aggressive growth and allow for a better development of white clover (Trifolium repens L.) when the two are seeded together (Gooding et al., 1996).

The objective of this study was to determine if, under the prevailing soil and climatic conditions in the Los Rios Region (Chile), ploidy of L. perenne cultivars affect herbage production, nutritional quality and grazing preference of dairy cows. 


\section{MATERIALS AND METHODS}

The study was carried at the Vista Alegre Experimental Station of the Universidad Austral de Chile, $6 \mathrm{~km}$ north of the city of Valdivia ( $\left.39^{\circ} 47^{`} \mathrm{~S}, 73^{\circ} 13^{`} \mathrm{~W}\right)$ and lasted 3 years, from April 1999 to May 2002.

The climate in the area is characterized by an average annual temperature of $12.1^{\circ} \mathrm{C}$, with a maximum mean monthly value of $16.9^{\circ} \mathrm{C}$ in January and a minimum of $7.6{ }^{\circ} \mathrm{C}$ in July. Average annual precipitation is close to $2500 \mathrm{~mm}$ (Huber, 1970). The monthly precipitation values during the experimental period are presented in Table 1.

Table 1. Annual rainfall during the experimental period (April 1999 to March 2002) and 40-year monthly average in Valdivia.

\begin{tabular}{lrrrr}
\hline Month & Year 1 & Year 2 & Year 3 & $\begin{array}{c}\text { 40-year } \\
\text { average }\end{array}$ \\
\cline { 2 - 3 } \cline { 5 - 5 } April & 45.9 & 145.5 & 97.6 & 157.8 \\
May & 244.4 & 181.9 & 361.2 & 344.2 \\
June & 421.2 & 934.8 & 417.1 & 367.5 \\
July & 244.9 & 333.1 & 588.3 & 373.3 \\
August & 454.6 & 239.0 & 261.6 & 300.2 \\
September & 265.4 & 214.9 & 107.3 & 186.6 \\
October & 45.8 & 133.1 & 54.8 & 142.5 \\
November & 105.4 & 125.8 & 94.1 & 98.1 \\
December & 67.3 & 70.3 & 9.5 & 90.2 \\
January & 31.7 & 143.0 & 36.7 & 66.9 \\
February & 219.0 & 39.6 & 90.2 & 55.8 \\
March & 84.2 & 76.6 & 269 & 79.0 \\
Annual total & 2229.8 & 2637.6 & 2387.4 & 2262.1 \\
\hline
\end{tabular}

According to the classification of ecoregions proposed by Gastó et al. (1987), this area belongs to the Temperate Kingdom, Humid Domain, and Cool Summer Province. The soil belongs to the Valdivia series (Typic Hapludand), with plane topography (3\%) without drainage problems. A soil analysis was conducted in March of each year (Soil Laboratory of the Soil Science Institute, Universidad Austral de Chile). Samples were taken to a depth of $20 \mathrm{~cm}$ (Table 2).

Fertilizers were applied annually to meet the requirements of a pasture with a potential production of 14 t DM ha-1 (Table 3). Nitrogen fertilizers were applied in seven applications of $30 \mathrm{~kg} \mathrm{~N} \mathrm{ha}^{-1}$ each. The other nutrients were applied once a year in March.

The $L$. perenne cultivars were sown in previously prepared soil on April 16, using a Planet Junior manual seeder. Seeding was in rows with a separation of $20 \mathrm{~cm}$. The seed dosage was $30 \mathrm{~kg} \mathrm{ha}^{-1}$. To control Listronotus bonariensis Kuschel, the seeds were disinfected with imidacloprid ( $70 \% \mathrm{WP}$, ANASAC, Chile), using a dosage of $105 \mathrm{~g} \mathrm{ha}^{-1}$ of active ingredient.

Four tetraploid cultivars (4n): Quartet, Gwendal, Pastoral, Napoleon, and four diploid cultivars (2n) Anita, Jumbo, Aries, and Yatsyn 1 were evaluated. The

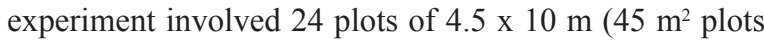
and $1080 \mathrm{~m}^{2}$ total trial).

\section{Experimental design}

An experimental design with randomized complete blocks was used, adding two types of ploidy (diploids and tetraploids) and four cultivars per ploidy, with three blocks, according to the model (Ott, 1993):

$$
\mathrm{Y}_{\mathrm{ijk}}=\mu+\mathrm{Qi}+\eta_{\mathrm{j}(\mathrm{i})}+\mathrm{Q}_{\mathrm{h}} * \eta_{\mathrm{e}}+\beta_{\mathrm{j}}+\varepsilon_{\mathrm{ehj}}
$$

Table 2. Soil fertility test at the beginning of the study, before establishment (year 1) and at the beginning of the second and third year.

\begin{tabular}{lccc}
\hline Parameter & Year 1 & Year 2 & Year 3 \\
\hline Water pH $(1: 2,5)$ & 5.2 & 5.9 & 5.8 \\
$\mathrm{CaCl}_{2} \mathrm{pH}(1: 2,5)$ & 4.8 & 5.3 & 5.2 \\
Organic matter, \% & 12.8 & 11.6 & 17.5 \\
Mineral N, mg kg-1 $\mathrm{N}^{-N^{3}}$ & 49.0 & 33.6 & 17.9 \\
Olsen phosphorus, mg kg-1 & 16.5 & 14.0 & 12.2 \\
Interchangeable potassium, mg kg-1 & 289 & 200 & 270 \\
Interchangeable sodium, cmol+ kg-1 & 0.11 & 0.09 & 0.04 \\
Interchangeable calcium, cmol+ kg-1 & 3.15 & 7.00 & 9.21 \\
Interchangeable magnesium, cmol+ $\mathrm{kg}^{-1}$ & 0.62 & 0.46 & 0.61 \\
Sum of interchangeable bases, cmol+ kg-1 & 4.62 & 8.06 & 10.56 \\
Interchangeable aluminum, cmol+ kg-1 & 0.19 & 0.10 & 0.19 \\
Saturation of aluminum, \% & 4.0 & 1.20 & 1.90 \\
Available sulphur, mg kg-1 & & 44.8 & \\
\hline
\end{tabular}


Table 3. Fertilizer application levels and products used in the experiment.

\begin{tabular}{lcccl}
\hline Nutrient & Year 1 & Year 2 & Year 2 & Products used \\
\cline { 2 - 3 } & & kg ha $^{-1}$ & \\
$\mathrm{CaCO}_{3}$ & 4000 & 0 & 0 & Soprocal \\
$\mathrm{P}_{2} \mathrm{O}_{5}$ & 140 & 120 & 70 & Super Triple Phosphate \\
$\mathrm{N}$ & 210 & 210 & 210 & Hydro sulphan, urea \\
$\mathrm{K}_{2} \mathrm{O}$ & 150 & 70 & 70 & Potassium muriate, Sulpomag \\
$\mathrm{MgO}$ & 37 & 30 & 30 & Sulpomag \\
$\mathrm{S}$ & 45 & 45 & 45 & Sulpomag, Hydro sulphan \\
Micro-elements & 25 & 25 & 25 & Micro-elements Fröhlich $^{1}$ \\
\hline
\end{tabular}

${ }^{1}$ Composition: $20 \% \mathrm{MgSO}_{4}, 20 \% \mathrm{MgO}, 25 \%$ borax, $10 \% \mathrm{ZnSO}_{4}, 1 \%$ Mo trioxide, and $24 \% \mathrm{CaCO}_{3}$.

where, $\mathrm{Y}_{\mathrm{ijk}}$ is the observation, $\mu$ is the population mean, Qi is the effect of the ith ploidy, $\eta_{\mathrm{j}(\mathrm{i})}$ is the effect of the jth cultivar within the ploidy, $\beta_{\mathrm{k}}$ the effect of the kth block and $\varepsilon_{\text {ehj }}$ is the experimental error.

The results were submitted to variance analysis with a $5 \%$ level of significance. This work reports the corresponding results to the effect of the ploidy of the cultivars.

\section{Evaluated variables}

The number of plants established was determined on June 22 (67 days after seeding), taking five rows of each plot at random and a random $20 \mathrm{~cm}$ long section within each row, in which the number of plants was measured. The result of this measurement was expressed as the number of plants per $\mathrm{m}^{2}$. The initial tillering was evaluated on August 2 (108 days after seeding), taking 30 complete plants at random from each plot, of which the number of tillers and leaves per tiller were counted and the length of plants was measured from the soil level to the apex of extended leaves. Additionally, the dry weight of each plant was determined by drying them at $60^{\circ} \mathrm{C}$ for $72 \mathrm{~h}$. The vigor of the establishment was evaluated when all the seedlings from each plot emerged (May 25). The cv. Yatsyn 1 was treated as a control for this evaluation and compared visually with the other cultivars within the same block. A scale of 1 (minimum vigor) to 7 (maximum vigor) was used, in which the control cultivar (Yatsyn 1) was assigned the value 4 .

The evaluations were made each time that the average of the cultivars reached a height of $20 \mathrm{~cm}$. All the plots were simultaneously grazed. Twenty grazing events were carried out over the evaluated period. The available herbage mass and pre- and post-grazing were measured by cutting a strip $1.1 \mathrm{~m}$ wide by $8.9 \mathrm{~m}$ long to a height of $4 \mathrm{~cm}$. Prior to the evaluation, a $0.55 \mathrm{~cm}$ area of border was eliminated from each plot. Sub-samples were obtained from the harvested forage to determine botanical composition ( $L$. perenne and other species), dry matter content (DM) and nutritional analysis. The latter was done at the Animal Nutrition Laboratory at the Universidad Austral de Chile. DM was determined in a ventilation oven at $60{ }^{\circ} \mathrm{C}$ for 48 $\mathrm{h}$ and in a stove at $105^{\circ} \mathrm{C}$ for $12 \mathrm{~h}$. Crude protein (CP) was determined by Micro-Kjeldahl (Bateman, 1970) and the digestibility of organic matter in DM (D value) using a modified version of the method of Tilley and Terry (Goering and Van Soest, 1972).

After obtaining pre-grazing samples, the cultivars were grazed simultaneously by eight lactating cows. Grazing preference was evaluated following the afternoon milking for a period of $2.5 \mathrm{~h}$, registering every $5 \mathrm{~min}$ in which plot a cow was grazing. Based on this information, the grazing time in each plot was calculated through applying the methodology used by Phillips et al. (1999). The cows were kept grazing the experimental plots for 24 $\mathrm{h}$, after which the post-grazing residue of each plot was evaluated by cutting to a height of $4 \mathrm{~cm}$ in a procedure analogous to that of the pre-grazing. Finally, all of the experimental area was cut to a uniform height of $4 \mathrm{~cm}$.

The utilization efficiency of each grazing was calculated by relating apparent DM intake from each plot to the herbage mass offered in pre-grazing (herbage mass offered in the pre-grazing minus the residual herbage mass, both measured above $4 \mathrm{~cm}$ ).

\section{RESULTS AND DISCUSSION}

\section{Establishment}

All the cultivars exceeded 450 plants $\mathrm{m}^{-2}$ (Table 4), a level of density that Muslera and Ratera (1991) considered adequate in the establishment of $L$. perenne. The plots with diploid cultivars had a higher number of plants than those with tetraploids, a difference that is explained by having used equal seeding rate $\left(30 \mathrm{~kg} \mathrm{ha}^{-1}\right)$ for the sowing without having corrected for the larger size of tetraploid seeds (Gilliland et al., 2002). For the other variables measured during the period of establishment, significant differences were only detected in the number 
Table 4. Plant features during the establishment period of diploid and tetraploid Lolium perenne cultivars.

\begin{tabular}{|c|c|c|}
\hline \multirow[b]{2}{*}{ Variables evaluated } & \multicolumn{2}{|c|}{ Cultivars of $L$. perenne } \\
\hline & Diploids & Tetraploids \\
\hline Number of plants $\mathrm{m}^{-2}$ & $597 \mathrm{a}$ & $516 b$ \\
\hline Length of plant, $\mathrm{cm}$ & $11.4 \mathrm{a}$ & $12.0 \mathrm{a}$ \\
\hline Number of tillers plant ${ }^{-1}$ & $3.3 \mathrm{a}$ & $3.2 \mathrm{a}$ \\
\hline Number of leaves tiller-1 & $3.1 \mathrm{a}$ & $3.2 \mathrm{~b}$ \\
\hline Dry weight tiller ${ }^{-1}, \mathrm{mg}$ tiller $^{-1}$ & $28.4 \mathrm{a}$ & $31.8 \mathrm{a}$ \\
\hline Vigor (scale 1 to 7 ) & $4.5 \mathrm{a}$ & $4.3 \mathrm{a}$ \\
\hline
\end{tabular}

Values on the same row followed by different letters present significant differences (ANOVA, P $\leq 0.05$ ).

of leaves per tiller; with the tetraploid cultivars having a slightly higher number. The weights of the tillers were not significantly different $(\mathrm{p}>0.05)$, as was expected, which suggest that this characteristic is not expressed early in the development of the pasture.

\section{Accumulated herbage mass}

The contribution of $L$. perenne as a proportion of harvested herbage mass was on average above $90 \%$ during the 3 years, without significant differences due to the effect of the ploidy of the cultivars. The group of the other species was mainly represented by Bromus valdivianus Phil., Holcus lanatus L. and Leontodon nudicaulis (L.) Banks ex Schinz \& R. Keller. The values of accumulated herbage mass (Table 5) correspond to the L. perenne yield as a pure species. During the 3 years of the evaluation, the diploid cultivars had a higher herbage mass yield than the tetraploids (Figure 1). Annual accumulated herbage mass (Table 5) was significantly higher each year for the diploid cultivars. In environments with constraints, such as those with soil fertility restrictions and summer water deficits, as is often the case with agroecological systems in southern Chile, diploid cultivars show advantages in herbage mass production compared to tetraploid cultivars because of greater stress tolerance (Sugiyama, 2006). Probably a contrary response would be expected when the cultivars are developed in environments with a low level of stress, for example, with high soil fertility, a high addition of fertilizers $\left(290 \mathrm{~kg} \mathrm{~N} \mathrm{ha}^{-1}, 144 \mathrm{~kg} \mathrm{P}_{2} \mathrm{O}_{5}\right.$ $\mathrm{ha}^{-1}$ and $375 \mathrm{~kg} \mathrm{~K}_{2} \mathrm{O} \mathrm{ha}{ }^{-1}$ ) and without water restrictions, as was reported by Gilliland et al. (2007) in Northern Ireland, where tetraploid cultivars shown a higher annual production of forage. This supports the hypothesis of a trade-off between the capacities of a genotype to capture nutrients from the soil and transform them into herbage mass compared to the comparison to tolerate diverse environmental stresses (Tilman, 1988).

\section{Nutritive quality}

During the 20 grazing events evaluated in the 3 years, the levels of CP were similar for the diploid and tetraploid cultivars, varying between 10 and $25 \%$ of DM, with characteristic fluctuations that occur in pasture grasses during the year: the minimal contents in the summer period and maximum at the beginning of spring (Figure 2). The annual average CP concentration, weighted by DM production, did not show significant differences $(\mathrm{p}>$ 0.05 ), with values that fluctuated in the range of 16 to $20 \%$ (Table 6), supporting that L. perenne under grazing and growing under the edaphoclimatic conditions of southern Chile, is capable of producing good levels of protein throughout the year, compatible with the requirements of dairy cows.

Table 5. Accumulated herbage mass and pasture pregrazing height of diploid and tetraploid Lolium perenne cultivars.

\begin{tabular}{|c|c|c|c|c|}
\hline \multirow{3}{*}{ Year of evaluation } & \multicolumn{4}{|c|}{ Cultivars of Lolium perenne } \\
\hline & \multicolumn{2}{|c|}{ Diploids } & \multicolumn{2}{|c|}{ Tetraploids } \\
\hline & Herbage mass & Height & Herbage mass & Height \\
\hline & $\mathrm{kg} \mathrm{DM} \mathrm{ha-1}$ & $\mathrm{cm}$ & kg DM ha-1 & $\mathrm{cm}$ \\
\hline First year & $12549 \mathrm{a}$ & $21.8 \mathrm{a}$ & $11496 b$ & $20.1 b$ \\
\hline Second year & $10108 \mathrm{a}$ & $20.9 \mathrm{a}$ & $8900 b$ & $19.7 b$ \\
\hline Third year & $9912 \mathrm{a}$ & $22.9 a$ & $8749 b$ & $21.5 b$ \\
\hline
\end{tabular}

Values on the same row followed by different letters present significant differences (ANOVA, P $\leq 0.05$ ). 

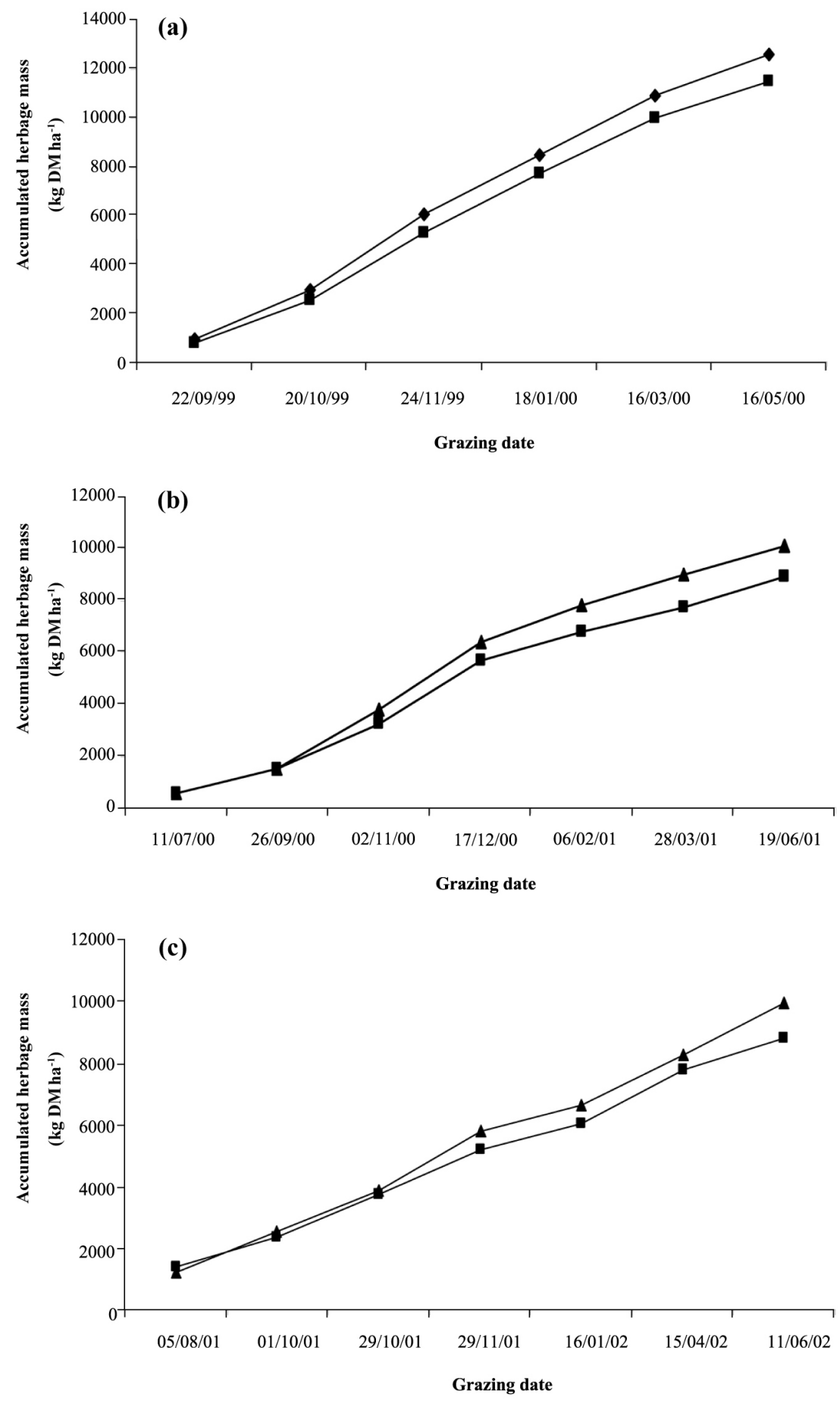

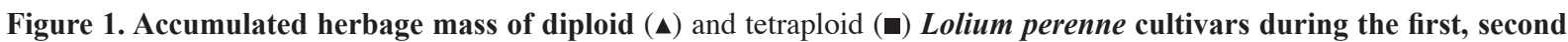
and third evaluation year. 


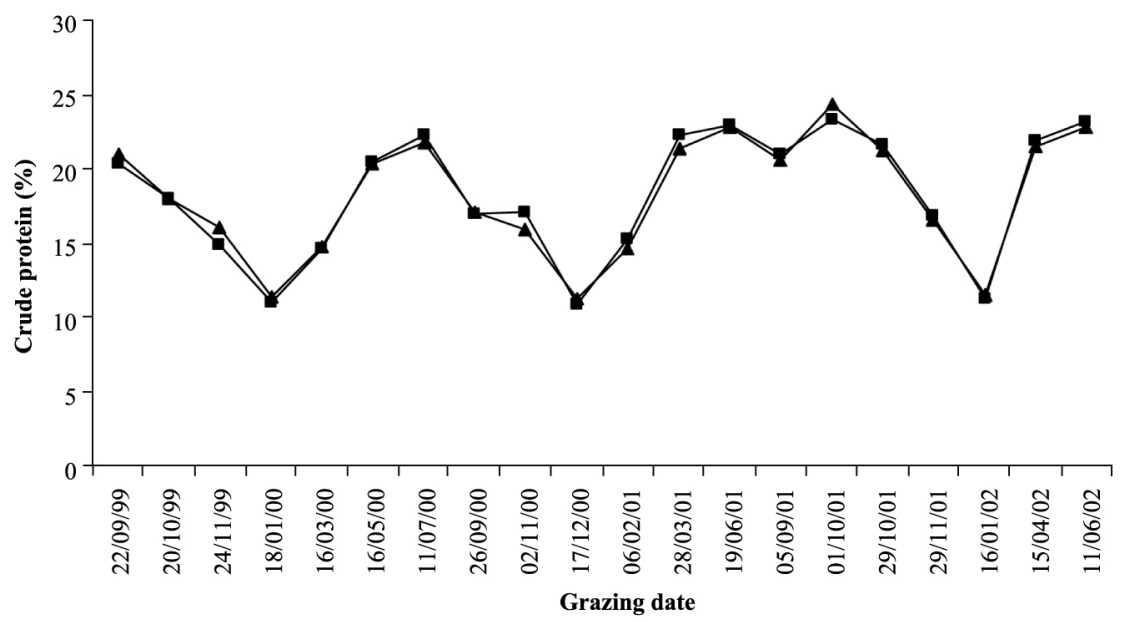

Figure 2. Evolution of crude protein content of diploid ( $\Delta$ ) and tetraploid ( $\square$ ) Lolium perenne cultivars over 3 years (\% DM basis).

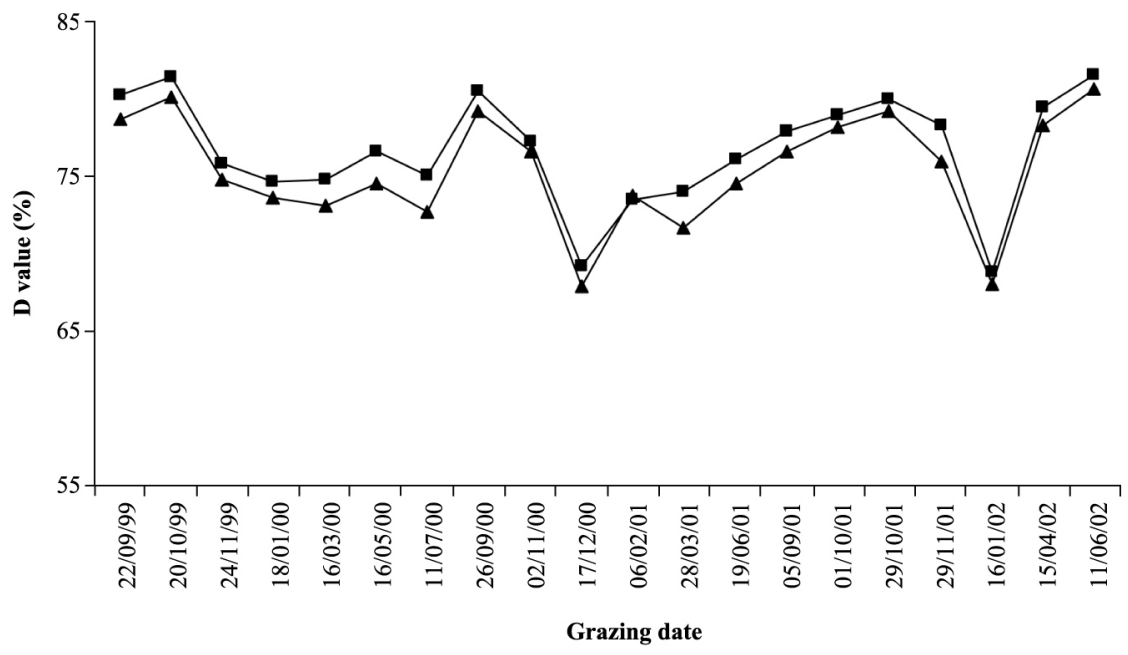

Figure 3. Evolution of D value of diploid ( $\Delta$ ) and tetraploid ( $\square$ ) Lolium perenne cultivars over 3 years (\% DM basis).

Figure 3 show that the tetraploid cultivars consistently had higher digestibility (D value) than the diploid cultivars. The lowest $\mathrm{D}$ value measured for the diploid cultivars was $67.8 \%$ and for the tetraploids it was $68.8 \%$. The maximum value was de $80.6 \%$ for the diploids and $81.5 \%$ for the tetraploids. The average annual $\mathrm{D}$ value was significantly higher $(\mathrm{p}<0.05)$ for the tetraploid cultivars, excepting the third year of evaluation, when it was not significant $(p>0.05)$ (Table 6). These results are in agreement to those reported by O'Donovan and Delaby (2005) and are explained by the morphological characteristics of tetraploid cultivars, which have a higher cellular content/ cell wall ratio, which confers higher digestibility of the DM produced.

\section{Grazing preference}

The lactating cows grazed significantly more tetraploid cultivars (Table 7), even though the greater pre-grazing height of the diploid cultivars (Table 5) and considering that higher pre-grazing height is one of the factors that increase grazing preference (Phillips et al., 1999). This greater preference for tetraploid cultivars was 
Table 6. Annual weighted average of crude protein content and D value of diploid and tetraploid Lolium perenne cultivars (\% DM basis).

\begin{tabular}{lcc}
\hline & \multicolumn{3}{c}{ Cultivars of $L$. perenne } \\
\cline { 2 - 3 } Variables and year of evaluation & Diploids & Tetraploids \\
\hline Crude protein & & $15.7 \mathrm{a}$ \\
First year & $16.2 \mathrm{a}$ & $16.8 \mathrm{a}$ \\
Second year & $16.4 \mathrm{a}$ & $20.2 \mathrm{a}$ \\
Third year & $20.0 \mathrm{a}$ & \\
D value & & $76.4 \mathrm{a}$ \\
First year & $75.1 \mathrm{~b}$ & $74.2 \mathrm{a}$ \\
Second year & $72.9 \mathrm{~b}$ & $77.9 \mathrm{a}$ \\
Third year & $76.9 \mathrm{a}$ & \\
\hline
\end{tabular}

Values on the same row followed by different letters present significant differences (ANOVA, $\mathrm{P} \leq 0.05$ ).

consistent and significant during the 3 years of evaluation. The three variables considered in this study to measure grazing preference (grazing time, residual herbage mass and percentage of pasture utilization) were consistent in showing this difference. The grazing time, measured in a period of $2.5 \mathrm{~h}$ after the afternoon milking, showed a significantly higher grazing time $(p<0.05)$ for the tetraploid cultivars over the 3 years. Residual herbage mass (measured over $4 \mathrm{~cm}$ ) was significantly higher in the diploid cultivars, indicating more rejection of the forage in the pasture. It should be considered that all the plots were homogenized to the same height after each grazing. The percentage of pasture utilization, which corresponds in this case to the ratio between apparent intake and pre- grazing herbage mass offered, was significantly higher in the tetraploid cultivars in the 3 years (Table 7). These results indicate that the dairy cows grazed preferentially on the tetraploid cultivars and with greater intensity. This response would be partially explained by the greater digestibility (D value) of the tetraploid cultivars (Figure 3). Stilmant et al. (2005) reported greater grazing preference for tetraploid cultivars of $L$. perenne, emphasizing the importance that digestibility exercises as a determining factor in preference and selection of grazing animals. The higher concentration of soluble carbohydrates that characterize tetraploid cultivars (Gilliland et al., 2002) probably contributes to explaining the observed grazing preference.

Table 7. Grazing preference, residual herbage mass and pasture utilization percentage of diploid and tetrapliod $\mathrm{Lolium}$ perenne cultivars.

\begin{tabular}{lcc}
\hline & \multicolumn{2}{c}{ Lolium perenne cultivars } \\
\cline { 2 - 3 } Variables and year of evaluation & Diploids & Tetraploids \\
\hline${\text { Grazing preference, } \text { min }_{\text {plot }}{ }^{-1}}$ & $19.9 \mathrm{~b}$ & $24.7 \mathrm{a}$ \\
First year & $20.4 \mathrm{~b}$ & $26.1 \mathrm{a}$ \\
Second year & $27.0 \mathrm{~b}$ & $29.0 \mathrm{a}$ \\
Third year & & \\
Residual herbage mass, kg MS ha-1 & $518 \mathrm{a}$ & $382 \mathrm{~b}$ \\
First year & $382 \mathrm{a}$ & $285 \mathrm{~b}$ \\
Second year & $224 \mathrm{a}$ & $168 \mathrm{~b}$ \\
Third year & & \\
Pasture utilization efficiency, \% & $75.9 \mathrm{~b}$ & $80.8 \mathrm{a}$ \\
First year & $68.9 \mathrm{~b}$ & $74.0 \mathrm{a}$ \\
Second year & $89.2 \mathrm{~b}$ & $91.0 \mathrm{a}$ \\
Third year &
\end{tabular}

Values on the same row followed by different letters present significant differences (ANOVA, $\mathrm{P} \leq 0.05$ ). 


\section{CONCLUSIONS}

Under the soil and climatic conditions of southern Chile, characterized by fluctuations in summer precipitation and the absence of irrigation, the diploid cultivars of $L$. perenne showed higher accumulated herbage mass per hectare than the tetraploid cultivars. However, the tetraploid cultivars, which presented higher energy concentration (D value) are preferred and are more intensely grazed by the dairy cows than the diploid cultivars.

\section{RESUMEN}

Producción de fitomasa, calidad nutritiva y preferencia de pastoreo de cultivares diploides y tetraploides de ballica perenne (Lolium perenne L.). El objetivo de este estudio fue determinar, bajo las condiciones edafoclimáticas del sur de Chile, el efecto de la ploidía de cultivares de ballica perenne (Lolium perenne L.) sobre el rendimiento de fitomasa, calidad nutricional, preferencia de pastoreo y porcentaje de utilización del forraje producido. El ensayo se realizó en el sur de Chile, provincia de Valdivia, y se evaluó por 3 años. Se utilizaron los cultivares tetraploides Quartet (4n), Gwendal (4n), Pastoral $(4 n)$ y Napoleón $(4 n)$. Los cultivares diploides Anita (2n), Jumbo (2n), Aries (2n) y Yatsyn $1(2 n)$. Vacas lecheras pastorearon simultáneamente durante 24 $\mathrm{h}$ todas las parcelas cuando éstas alcanzaron una altura promedio de $20 \mathrm{~cm}$. Previo y posterior a cada pastoreo se midió altura de la pradera, fitomasa y valor nutritivo. La preferencia de pastoreo fue evaluada visualmente cada 5 min durante un período de $2,5 \mathrm{~h}$ posterior a la ordeña de la tarde. Durante el período de 3 años se evaluaron 20 pastoreos. El diseño experimental fue de bloques completos al azar con ocho cultivares y tres bloques. Los cultivares diploides presentaron un mayor rendimiento de materia seca $(\mathrm{P} \leq 0,05)$. No se detectaron diferencias significativas en el contenido de proteína. Sin embargo, los cultivares tetraploides presentaron un mayor valor $\mathrm{D}$, aunque esta diferencia no fue significativa en el tercer año. Las vacas en lactancia pastorearon significativamente más tiempo sobre los cultivares tetraploides. Considerando la fitomasa residual pospastoreo y el porcentaje de utilización se puede indicar que las vacas pastorearon menos intensamente los cultivares diploides.

Palabras clave: Lolium perenne, preferencia de pastoreo, fitomasa, ploidía.

\section{LITERATURE CITED}

Bateman, J. 1970. Nutrición animal. Manual de métodos analíticos. 468 p. Centro Regional de Ayuda Técnica, México.

Gastó, J., S. Gallardo, y D. Contreras. 1987. Caracterización de los pastizales de Chile. Reinos, dominios y provincias. Santiago, Chile. Sistemas en Agricultura. Teoría-Avances. Vol. 9. 292 p.

Gilliland, T., P. Barrett, R. Mann, R. Agnew, and A. Fearon. 2002. Canopy morphology and nutritional quality traits as potential grazing value indicators for Lolium perenne varieties. J. Agric. Sci. (Cambridge)139:257-273.

Gilliland, T., J. Johnson, and C. Connolly. 2007. A review of forage grass and clover seed use in Northern Ireland, UK, between 1980 and 2004. Grass Forage Sci. 62:239-254.

Goering, H., and P. Van Soest. 1972. Forage fiber analysis. USDA Agric. Handbook No 379. 41 p. Agricultural Research Service, Ithaca, New York, USA.

Gooding, R., J. Frame, and C. Thomas. 1996. Effects of sward type and rest periods from sheep grazing on white clover presence in perennial ryegrass/white clover associations. Grass Forage Sci. 51:180-189.

Huber, A. 1970. Diez años de observaciones climatológicas en la estación Teja-Valdivia (Chile) 1960-1969. Valdivia. Serie $N^{\circ}$ 1. 60 p. Universidad Austral de Chile, Facultad de Ciencias Naturales y Matemáticas, Instituto de Geografía y Geología, Valdivia, Chile.

Muslera, E., y C. Ratera. 1991. Praderas y forrajes. $2^{a}$ ed. 674 p. Ediciones Mundi-Prensa, Madrid, España.

Myers, W. 1939. Colchicine induced tetraploidy in perennial ryegrass. J. Heredity 30:499-504.

Nair, R. 2004. Developing tetraploid perennial ryegrass (Lolium perenne L.) populations. N.Z. J. Agric. Res. 47:45-49.

O'Donovan, M., and L. Delaby. 2005. A comparison of perennial ryegrass cultivars differing in heading date and grass ploidy with spring calving dairy cows grazed at two different stocking rates. Anim. Res. 54:337-350.

Ott, R.L. 1993. An introduction to statistical methods and data analysis. 1051 p. $4^{\text {th }}$ ed. Duxbury Press, Belmont, California, USA.

Phillips, C., M. Youssef, and P. Chiy. 1999. The effect of introducing timothy, cocksfoot and red fescue into a perennial ryegrass sward and the application of sodium fertilizer on the behavior of male and female cattle. Appl. Animal Behav. Sci. 61:215-226.

Sheldrick, R.D. 2000. Sward establishment and renovation. p. 13-30. In Hopkins, A. (ed.) Grass, its production and utilization. $3^{\text {rd }}$ ed. Blackwell Science, Oxford, UK. 
Smith, K., R. Simpson, R. Culvenor, M. Humphreys, M. Prud'homme, and R. Oram. 2001. The effects of ploidy and a phenotype conferring a high water soluble carbohydrate concentration on carbohydrate accumulation, nutritive value and morphology of perennial ryegrass (Lolium perenne). J. Agric. Sci. (Cambridge) 136:65-74.

Stilmant, D., P. Limbourg, and P. Lecomte. 2005. Assessment of cattle preference for perennial ryegrass varieties in association with white clover. Does white clover content interfere? J. Agron. Crop Sci. 191:233240.
Sugiyama, S. 2006. Responses of shoot growth and survival to water stress gradient in diploid and tetraploid populations of Lolium multiflorum and $L$. perenne. Grassland Sci. 52:155-160.

Tilman, D. 1988. Plant strategies and the dynamics and structure of plant communities. 360 p. Princeton University Press, Princeton, New Jersey, USA. 